2020 TheoLogica

An International Journal for Philosophy of Religion and Philosophical Theology

S. I. CONCILIAR TRINITARIANISM

DOI: https://doi.org/10.14428/thl.v4i2.54423

\title{
God Is not a Thing: A Response to Dale Tuggy
}

ANDREW RADDE-GALLWITZ

University of Notre Dame

araddega@nd.edu

\begin{abstract}
Dale Tuggy has argued that all Trinitarians are committed to the nonsensical belief that the one God is the Trinity (where "is" expresses identity). In his submission to the current journal, Tuggy argues that this position began not, as some Orthodox theologians have claimed, with Augustine, but rather with the Cappadocians. According to Tuggy, in these late fourth century authors, the Trinity "replaced" the Father as the one true God. In this response, it is argued (1) that Tuggy's thesis of historical replacement is unproven, (2) that Tuggy's concept of substance, and therefore his reading of the Cappadocians is anachronistic or confused, and (3) that Tuggy mistakes the names "God" and "Father" for proper names.
\end{abstract}

Keywords: Cappadocians, Trinity, Substance, Gregory of Nyssa, Dale Tuggy

According to Dale Tuggy, the doctrine of the Trinity is a mistake whose roots can be traced to a discernable moment in the history of the church. On his reading, the late fourth century first witnessed the erroneous opinion, ubiquitous in subsequent orthodox Christianity, that the one God is the Trinity rather than the Father alone. In "When and How in the History of Theology Did the Triune God Replace the Father as the Only True God?" (hereinafter, "Replace"), Tuggy's task is historical diagnosis: "the tell-tale mark of someone who believes in the triune God is the use of 'the Trinity' as a singular referring term, one that can be interchanged with 'God'." Accordingly, "To find believers in a triune God, then, we are looking for some term like 'the Trinity' which they use to refer to the one God, understood as including the Father, Son, and Spirit."

Tuggy sees no need in "Replace" to labor over Latin Christianity and its modern heirs. After all, already in Augustine's De Trinitate the famous phrase appears: "the Trinity that is God" (e.g. I.2.7, cited by Tuggy at note 82; cf. De civitate Dei XI.10). ${ }^{1}$ We might debate what Augustine means here, but I want to leave the bishop of Hippo largely to the side, given the focus of the article to which I am responding.

\footnotetext{
${ }^{1}$ For background and discussion, see Lewis Ayres (2010, 96-103).
} 
"Replace" rebuts those who try to save Trinitarianism by claiming that a Trinitarian believer need not identify the Trinity with the one God, as Augustine and his followers purportedly do. In particular, Tuggy responds to those Eastern Orthodox theologians who claim that a Trinitarian theologian can and indeed ought to speak, as Tuggy himself does, of the Father as the one God, without denying the divinity of the Son and Spirit. Orthodox authors such as John Behr and Beau Branson have argued for the orthodoxy of the claim that the Father is the one God and have unsurprisingly traced the problematic identification of Trinity with God to Augustine and the subsequent Latin tradition. By Tuggy's standards, Branson's Monarchian Trinitarianism simply isn't Trinitarianism, since, on his view, Trinitarianism requires the (false) identification of the Father, Son, and Spirit, collectively referred to as "Trinity," with the one God. That identification, he says, is "non-negotiable." As one can surmise, a lot of the debate hinges on whether one accepts this stipulation. Tuggy believes he can offer a historical narrative to support it. Crucially, the narrative of "Replace" denies what the Orthodox Monarchians affirm: that Augustine and the Latins are to blame for the misguided identification; for him, the Cappadocian Fathers instead bear the blame. The motivation appears to be that, if the error can be shown to be natively Hellenic, it becomes inescapable for any supporter of pro-Nicene doctrine, whether Eastern or Western.

\section{Preliminary Historical Questions}

There are a number of difficulties with Tuggy's argument, but we can begin with his history of Trinitarian doctrine. Say that one accepts Tuggy's reading of the Cappadocians and accepts that the identification of Trinity with God is erroneous. Would any believer today be obliged to accept the identification simply because it had been found in late fourth century Greek sources? It would seem that the only reason for them to do so would be the putative authority of the Cappadocians. No conciliar decree would oblige them to do so. The Nicene-Constantinopolitan Creed of 381, which I assume is the principal normative creedal statement on the matter, says "one God the Father almighty," a phrase which does not make the identification of the three persons with the one God.

On my reading, a lot of work is done by the verb "replace" in Tuggy's title: he posits that at some point, the triune God replaced the Father as solus verus deus. But to establish this replacement thesis, one would need to do more than cite the first theologians to make the replacement; one would need also to show both that the older view died out and that the new view took its place, and this would require working through post-fourth-century authors and conciliar decrees of both Greek 
and Latin tradition. Tuggy does cite a smattering of post-fourth-century texts, but only the Latin ones make the identification he's looking for. He doesn't cite other Latin texts in which the explicit equation of "Trinity" and "God" does not appear, though many such texts do exist. But in the interest of responding directly to the argument as provided, I want to focus on works cited in "Replace." The passage Tuggy gives from the Council of Constantinople in 553 does not equate the Trinity with God, but rather glosses the phrase "consubstantial Trinity" with "one Deity to be adored in three subsistences or persons." 2 This kind of balanced expression (one deity in three hypostases) is quite common in creedal expressions from the late fourth century onwards and quite distinct from the identification of Trinity with God; its Cappadocian roots will be examined below. The same kind of expression appears in the Latin Tome of Damasus, which Tuggy cites. Even the later Latin texts cited by Tuggy that do identify Trinity and God don't by themselves make his point: all the examples show is that Augustine's apparent equation or identification of Trinity with God was endorsed, not that the other view (one divine nature or deity in three persons) was rejected. It is not impossible that these authors held both positions, especially if they, like Augustine, used the word "God" to refer to the divine nature, a position that is not as obviously incoherent as the one Tuggy dismisses. In sum, even if we grant Tuggy's reading of the Cappadocians, it does not prove any replacement, and therefore does not bear any sort of weight for traditional theologians. Those who adhere to a "Nicene development narrative," as he calls the opposing camp, tend not to speak of it as replacing earlier theology.

Tuggy does cite a handful of Reformation-era and more recent texts that appear to make the, to him, offensive identification of Trinity with God. Tuggy implies that such statements are somehow binding on believers in the Trinity and that they are merely the outworking of what the Cappadocians wrought long ago. (We can leave to the side whether Tuggy accurately represents the whole Trinitarian teaching of the Catechism of the Catholic Church; he at least captures part of it.) The important point is that all of the modern statements he cites come either from Catholic or Protestant churches in the Latin tradition or from modern Orthodox theologians who are employing the jargon of systematic theology. None of the citations is of an intrinsically authoritative text-that is, a document whose teaching authority supersedes that of the sources it cites. (Incidentally, this includes the Catechism of the Catholic Church.) Nor is there any obvious link between the modern texts cited by

2 I leave to the side the phrase "consubstantial Trinity," which came to prominence in Greek Christianity after the Cappadocians, who didn't use it. I don't think the phrase by itself has the implication of equating God with Trinity in Tuggy's sense, but a fuller study would be needed to show how authors used the phrase. The 553 Council offers a gloss that makes its point clear enough. 
Tuggy and the fourth century. As those involved in the project of "recovering" or "retrieving" Nicene Trinitarianism would attest, there is a massive conceptual gap between the fourth century pro-Nicenes and modern systematic theology. ${ }^{3}$ In sum, if a replacement occurred, it is not clear that Tuggy has yet put his finger on the culprit, nor is it clear that one pattern of speech has entirely been eclipsed by another.

\section{The Cappadocians on Substance and Trinity Metaphysical Problems}

Nonetheless, getting the Cappadocians right is an intrinsically important task for many theologians, and so it is worthwhile asking whether Tuggy's account of their thought is sustainable in its own right and not simply as part of a general replacement thesis. I noted earlier that the 553 Council and the Tome of Damasus affirm a single deity in three hypostases. This complex affirmation is, mutatis mutandis, the point of the passages cited by Tuggy from Basil and Gregory of Nyssa. For Tuggy, it is not only unbiblical but also philosophically confused. I will turn to the passages themselves in a moment, but first it is necessary to show that the affirmation of a single deity in three hypostases, or, put differently, of a distinction of hypostases in the unity of the deity, is not incoherent-or at least not in the way Tuggy claims it to be. We must underscore that the confession is complex, and indeed is necessarily so. On Tuggy's reading, Trinitarian belief is expressed in a rather simple balanced equation. On one side is either "the Trinity" or "the Father, Son, and Holy Spirit (collectively)" and on the other side is "the one God." It's bad math. Fortunately, the doctrine was usually expressed not in this way, but rather by such phrases as the one Tuggy cites from Gregory of Nyssa's Catechetical Oration, which affirms that the same divine nature is "both distinguished in hypostasis and

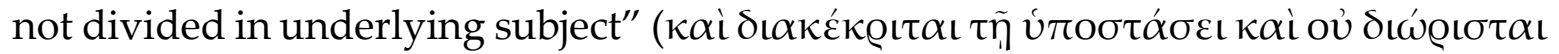
$\tau \tilde{\omega} \dot{\tau} \pi \mathrm{o \kappa \varepsilon} \mu \varepsilon \dot{v}(\omega)$.

Gregory distinguishes between hypostasis and underlying subject or substancehypokeimenon, which here does the work typically reserved in his texts for the terms physis (nature) and ousia (substance). Had he said that the same item is distinguished and not distinguished in the same respect, he would be committing a contradiction. The entire question therefore turns on whether one allows a distinction to be drawn between hypostasis and substance or nature - that is, between what is proper to each of the three whom Christ named in his baptismal formula and what is common to

\footnotetext{
${ }^{3}$ Outlined in the Epilogue to Lewis Ayres (2004).
} 
them. ${ }^{4}$ The twofold affirmation yields a corresponding double rule: one must neither separate the persons into distinct natures nor identify them with one another.

Now if the distinction of common and proper, and the corresponding twofold rule, were all there is to Trinitarian theology, we might be left with some unsettling results. In particular, the doctrine would appear to replicate, if only partially, how we think about universals in our ordinary experience. When we turn to the texts, we see the common/proper distinction was evidently judged to be necessary but also insufficient for a full doctrine of the Trinity. They also spoke of the three persons as inseparable in activity and in glory and so on, and therefore inconceivably more perfectly united than are members of species.

None of this traditional bundle of ideas can get off the ground with Tuggy, however, who is evidently uncomfortable with the initial distinction between common and particular in the case of God. He phrases this discomfort in various places, and it seems to me that there is something of a misunderstanding behind his objection. We see this perhaps most clearly in the following sentences:

Recall that the Nicene confession is that Father and Son are the same ousia. And going back to Aristotle, an ousia might be a thing, e.g. a man, or a kind-essence, e.g. humanity. The assumption was that this was a fundamental ambiguity in the term ousia, and that nothing could be both. But it seems to me that for Gregory here 'the single whole,' the Godhead/divine nature, is both that which is common to the persons (so, a kind-essence) but is also God, the triune God (so, a thing).

The root problem is the last word: thing. Tuggy thinks the patristic texts referred to God as a thing but contradicted themselves. By contrast, I don't think they spoke of God as a thing and therefore I don't see the contradiction. To get at the issue, we need to walk through the whole quotation step by step since it contains the core of Tuggy's philosophical assumptions. The first sentence offers an interpretation of the term homoousion in the Nicene Creed of 325, which professes belief in "the Lord Jesus Christ" as "homoousion with the Father" and "from the ousia of the Father" (the latter phrase does not appear in the Creed of Constantinople from 381). ${ }^{5}$ According to

\footnotetext{
${ }^{4}$ Various similar statements from Gregory and contemporary imperial legislation are discussed in Andrew Radde-Gallwitz (2018). See, e.g., Gregory, ep. 5: "All who walk by the rule of truth and confess the three hypostases that are piously recognized in their own characteristics and who believe there is one divinity, one goodness, one principle and authority and power ... these people, in our judgment, think the same [as we do] ..."; To Ablabius: "we confess the three hypostases and conceive of no difference of nature among them ... the single deity belongs to the Father, the Son, and the Holy Spirit".

${ }^{5}$ Mark DelCogliano (2017, 114-15).
} 
Tuggy, the homoousion means that the Son and Father "are the same ousia." He notes that ousia can have either of two senses, but not both. For Tuggy, it clearly cannot mean a kind, since the Son and Father are not the same kind. So he must take the other option: for the architects of the Nicene Creed, on his reading, the Son and Father are the same thing. This is a counterintuitive and highly implausible interpretation of the Creed. No one I'm aware of in the fourth century understood the phrase in this way. ${ }^{6}$ Nor could they, since it also says that the Son is "from the ousia of the Father." This phrase is ambiguous, but if the Son is from or of the Father's substance, surely he and the Father cannot be a single substance in the sense of a single thing. To be sure, the anathema attached to the 325 Creed takes the terms ousia and hypostasis as equivalents: it pronounces an anathema on anyone who says that the Son is of a different ousia or hypostasis than the Father. But at this time, Basil's stipulation that these two terms should be used for common and particular, respectively, had not yet been offered; it was not uncommon for the two to be used interchangeably. (Basil is aware that his stipulation breaks with custom). Therefore, the anathema cannot mean the following: the Son is not a different hypostasis (in Basil's sense) than the Father. It is merely reiterating whatever the adjective homoousion already says in the profession. To be sure, the meaning of that adjective is unspecified, but it certainly does not mean that Father and Son are the same thing.

Tuggy's second and third sentence are likewise problematic. He evidently is referring to the distinction in Aristotle's Categories between primary and secondary substance (ousia). I can say, of the same subject, "he is Socrates" or "he is human," and these reflect, respectively, the primary and secondary ways of ascribing substance to our subject, Socrates. The first addresses the individual; the second the individual's species membership. Aristotle would revise this position, or at least tackle the problem of substance in a much more thorough way, in his Metaphysics. There he notes that substance is spoken of in multiple ways, the most important of which are as matter, form, and the composite of the two. He argues that form (eidos) is most properly spoken of as substance. This reflects Aristotle's hylomorphism, which does not appear in the Categories. Within the hylomorphic scheme, the term eidos refers not to the species but rather the form inherent in particulars.

Although Tuggy represents his point as Aristotelian, he understands the ambiguity of substance differently, and it is this understanding that drives his criticism of the Cappadocians. He says that "nothing could be both" an individual

${ }^{6}$ There were theologians like Eustathius of Antioch and Marcellus of Ancyra who denied the eternal distinction of the Son or Word from the Father, but I don't know of a connection between this position and the Nicene homoousion. Nor do Eustathius and Marcellus seem to hold the position Tuggy names. See., e.g., Joseph Lienhard (1999). 
and a kind, the primary and secondary substances of Aristotle's Categories. While this is trivially true, it misses the point, since even though nothing is both itself and its species, everything within a kind is characterized by both its individual and its kind names. Tuggy understands the universal item differently from Aristotle; for Tuggy, the universal is a property or set of properties: "Divinity understood as a universal is by definition the property (or properties) which is (or are) sufficient to make something a god." Again: "One may well ask whether it is metaphysically possible for something to be both a universal essence which can be a property of many things and an individual entity with causal powers; but at any rate, this is Gregory [of Nazianzus]'s view." As a philosopher in the analytic tradition, Tuggy is compelled to think of universals as abstract entities exemplified by concrete particulars. In this scheme, only concrete items possess causal powers. This is the metaphysical dogma that drove Alvin Plantinga's well-known criticism of the doctrine of divine simplicity: according to the doctrine of divine simplicity, God is identical with any of God's properties; but God is a concrete item, a person; no person is identical with a property; etc. We can pass over the odd idea that God is a person and move directly to the philosophical confusion in the argument, which Nicholas Wolterstorff identified. ${ }^{7}$ Put simply, Plantinga was presupposing an analytic metaphysical scheme distinct from, and incompatible with, the traditional metaphysics he was criticizing. On the traditional metaphysics (e.g. the scholastic Aristotelianism of Thomas Aquinas), properties are not abstract entities exemplified by concrete particulars; rather, they are parts of particulars. As we have seen, in Metaphysics Z (VII), Aristotle describes individuals as composites of form and matter. On this view, the essential and accidental forms that constitute an individual are not causally inert "properties" but real components of that individual. Aristotle concludes that substantial form is the cause of the composite thing (Metaphysics Z (VII).17, 1041a-b). Moreover, some forms are capable of existing without matter: most notably, the active intellect of De anima III.5 and the Unmoved Movers of Metaphysics $\Lambda$ (XII); like forms in matter these separate forms are not causally inert. What's more, in patristic tradition, the nature or form of some subject is understood as that in virtue of which it acts in certain ways; hence all the debates about Christ's two sets of activities, divine and human, in later Christological debates. Thus, it is in virtue of Christ's humanity, for instance, that he walked. Moreover, his human will was held to reside in his human nature rather than in his composite hypostasis. This point would require much additional comment, but we need to note that in late antiquity, natures or substances were understood as being or at least necessarily

\footnotetext{
${ }^{7}$ Discussion and bibliography in William F. Vallicella (2019).
} 
including affective dispositions or capacities; they were not causally inert. At a minimum, Tuggy needs to acknowledge that his understanding of properties is alien to the texts he aims to interpret. Like Tuggy, I think that the Cappadocians are indebted in some way to Aristotle's concept of ousia (though this point requires historical and exegetical justification and will need to be qualified). I do not, however, see this concept in quite the way Tuggy does, and in particular, I doubt that they ever spoke of God in terms of the primary substance of the Categories.

Basil's Letter 236 to Amphilochius contains a useful passage to help us determine how the Cappadocians adjusted the broadly Aristotelian language for Trinitarian purposes.

Now substance (ousia) and hypostasis have the same difference that the common (to koinon) has with the particular (to kath' hekaston), as, for example, the animal has with such-and-such human being. Therefore, in the case of the divinity (epi tês theotètos) we confess, on the one hand, one substance, so that the formula of being (ton tou einai logon) is not defined in diverse ways, but on the other hand, a distinct hypostasis, so that we may have an unconfused and clear notion about the Father, Son, and Holy Spirit. For when we fail to grasp the characteristics that have been defined for each, for example, fatherhood, sonship, and holiness, and instead confess God on the basis of the common notion of being, it is impossible to give the account of the faith in a sound way. So then, that which is distinct must be added (prostithentas) to that which is common; one must confess the faith in this way. What is common is the divinity; what is distinctive is fatherhood. Joining these together (synhaptontas), one must say: "I believe in God the Father (eis theon patera)." And again in the confession of the Son one must do the same thing: join what is distinctive together with what is common and say: "[I believe] in God the Son (eis theon huion)." And likewise in the case of the Holy Spirit, one must form the utterance according to the logic of the expression and say: "I believe also in the divine Holy Spirit." In this way, then, the unity is completely preserved by the confession of the one divinity (theotêtos) and what is distinct to the persons (to tōn prosōpōn idiazon) is confessed by the definition of the distinguishing marks that are considered in connection with each of them. ${ }^{8}$

The passage shows how far Basil is from confusing the common and the particular. According to Basil, one must keep the two conceptually distinct, even as one joins them in the confession. The verbs he uses entail difference: one adds what is distinct to what is common and joins them together, though without erasing the difference between them. What is distinct and what is common? Here, they are concepts that represent, respectively, each hypostasis' unique feature(s) and the common formula

\footnotetext{
${ }^{8}$ Basil, ep. 236.6 (DelCogliano 2017b, 232; altered slightly for consistency).
} 
of deity. In a number of works, Basil uses the Aristotelian phrases logos tou einai and logos tēs ousias (formula of being, formula of substance) to unpack the meaning of the Nicene homoousion (already at Against Eunomius 1.19). For Basil, the point of this Nicene confession is that any term predicated substantially of any one hypostasis is predicated in precisely the same sense of the others; Basil takes "God from God, light from light, true God from true God" as examples. The only exceptions are those terms that serve only to distinguish each person. There is no single term nor a single invariant definition that stands in for Basil as the shared formula of substance for the deity, as "rational animal" might do for humanity. The formula in the case of deity presumably cannot include differentiae. But for Basil, it includes more than one term, since we have no proper name or single defining idea for God. Instead, for Basil as for Gregory of Nyssa after him, deity is what George Karamonolis helpfully calls a "cluster concept," including ideas of goodness, wisdom, incorruptibility, power, glory, and so on. ${ }^{9}$ It also includes fatherhood, sonship, and sanctifying holiness, but Basil thinks these function differently than the others, and the paragraph above spells out how.

The passage might raise numerous questions, and indeed a range of scholarly opinions can be offered on how the account of divine unity here fits with other passages in Basil's corpus, where he argues that the three persons are one in glory or in activity rather than in the formula of being. Yet, Basil never retracts the principle articulated here. Nor is it a once-off in his corpus, and there are similar passages in Gregory of Nyssa; some of the passages Tuggy cites from Nazianzen telescope the principle into brief expressions as well. Both Basil and Gregory (of Nyssa) affirm at once the unity of nature or power and the distinction in hypostasis. Both brothers articulate other models of divine unity in other passages that extend the concept of unity in ways not encompassed by the unity-and-difference principle articulated in the paragraph just cited. Even on its own terms, the comparison between an individual human being and, e.g., God the Father, cannot be perfect. For one thing, the species-term "human" and the genus-term "animal" are predicated identically an indefinite number of individuals, whereas "divine" is predicated according to the same formula of being of only three hypostases. To be sure, the same term "divine" is also predicated of other subjects - a point to which I will return-but not according to the identical formula or concept. For another thing, what differentiates each divine hypostasis is a unique property and only that, whereas individual human beings are differentiated in a whole host of ways. ${ }^{10}$

\footnotetext{
${ }_{9}^{9}$ George Karamonolis (Forthcoming).

${ }^{10}$ See Basil's account in Against Eunomius II.4 (2011, 134-35). A more orthodox Aristotelian would appeal to the distinct accidental forms in each individual's proximate matter for differentiation.
} 
Additionally, a primary substance in the Aristotelian sense is that which is numerically identical while admitting contrary states (Cat. 5, 4a10-11). Obviously it cannot be said of the Father, Son, or Holy Spirit that he admits contrary states. Still, Basil could acknowledge all of these shortcomings in the comparison between human individuals and divine hypostases without needing to withdraw his comparison altogether, since it provides a way of thinking about the necessary combination of shared and unique features.

The paragraph from Letter 236 is meant to distinguish Basil's interpretation of Nicene theology from Sabellianism. He was certainly aware of accusations of Sabellianism, and they would continue after his death. For instance, in the paragraph Tuggy cites from Eunomius' Expositio fidei (A.D. 383), Eunomius caricatures pro-Nicenes as though they taught that God is "split from a single substance into a threefold hypostasis." This is one example of an accusation of Sabellianism from a hostile source. While Basil might succeed in distancing himself from Sabellianism, it raises the opposing worry about tritheism; Tuggy is right that the Cappadocians present orthodoxy as a mean between these two. What of tritheism? Tuggy is unsatisfied with the answer implied by the passage above-that all one needs to affirm, when faced with allegations of tritheism, is a single deity common to the three hypostases. For him, "The tritheism-monotheism dispute is not about the number of universals such as divinity, but rather about the number of gods." To see why the Cappadocians saw it differently, we can turn the tables and ask what Tuggy has in mind when he speaks of God or gods. While Tuggy's paper doesn't contain his complete theology, it drops enough hints to enable us to draw some inferences; in the next section, I draw these out by focusing on the question of divine names.

\section{Divine Names}

Tuggy seems to be committed to the following theses: (1) God is a thing or a person, that is, a concrete individual entity with causal powers; (2) God and the Father are numerically identical; (3) "God" and "Father" function as proper names. The first two are more or less explicit in "Replace"; the third, which is my own reconstruction of Tuggy's line of thinking, appears to be the grounds for the second.

My reconstruction goes like this. Tuggy says his view that the one God is the Father alone is also the doctrine of the New Testament. Hence it is an interpretive position, a way of modeling or reproducing the logic of biblical sentences. Let's begin with "the Father." When a text uses this name, we must assume either that the term has reference but no meaning or that it has both reference and meaning. The 
former assumption would be that it functions as a proper name. "Dale Tuggy" does not have meaning but does have reference. The second assumption would be that "the Father" refers to some real subject and has meaning, indeed that the way in which it refers is under some description, just as if I referred to Dale Tuggy by saying "the American philosopher of religion" or "the author of an interesting antitrinitarian article in the recent TheoLogica" or "the son of Mr. and Mrs. Tuggy." This way of speaking refer to the particular man through concepts of a universal scope. Usually, we assume that proper names have no such meaning. ${ }^{11}$ In "Replace," and in Tuggy's podcast episode entitled "The Unfinished Business of the Reformation," which he cites in a footnote, Tuggy uses the term "Father" in such a way that implies it is a referring term, but not a term that requires any semantic explication. (One wonders of whom or what he is father). Indeed, so clear is the term's reference that "the Father" serves in turn as the normal referent of another term, "God" (ho theos), in the New Testament. For Tuggy, "God" is just another name for the Father. Tuggy's position that the one God just is the Father alone amounts to saying that "God" and "Father" function like "Mark Twain" and "Samuel Clemens" or "Cephas" and "Peter." In the podcast, Tuggy gives as a parallel to "Father" and "God" various nicknames or epithets used interchangeably for Donald Trump: "Mr. Trump," "The Donald," and "The Most Embarassing U.S. President Ever." The last one in this list does sneak in a meaning and is not strictly a proper name, but the point in context is that it is equivalent semantically with the others. The various titles can be substituted with no change of reference, and the same is true when "God" and "Father" are swapped in, for instance, John 17. "God" and "Father" therefore are for Tuggy interchangeable proper names in the authoritative source. This provides grounds for thinking that the one God just is the Father.

Tuggy's linguistic view contrasts with that of the Cappadocians. Basil and Gregory of Nyssa take "God" and "Father" to signify concepts. In fact, these terms signify distinct concepts, even though that they can be used to refer to the same subject. Basil, for instance, acknowledges various ways in which terms can overlap. In one type of case, which was called in late antiquity a polyonym but corresponds to our notion of synonymous terms, a single item has different names with a common meaning. This is how Basil understands cases like "Cephas" and "Peter" (and is probably how we would handle Tuggy's examples). When discussing polyonyms, the Neoplatonist Porphyry (possibly Basil's source) gives the examples of the terms "sword," "sabre," and "blade."12 Basil does not think that the various

${ }^{11}$ Interestingly, Basil appears to differ from the usual assumption on this. See Mark DelCogliano (2010).

12 Porphyry $(1992,50)$. 
divine names have the same meaning, though they do indicate the same referent, and so he thinks God is not a polyonym. Basil even denies that seemingly similar descriptions like "provident" and "foreknowing" are applied to God in this sense; although they refer to the same subject, each is distinct semantically. ${ }^{13}$ Since "Father" indicates a relation and "God" a substance, these two terms are distinct as well. ${ }^{14}$ Presumably Tuggy holds that God can be described with other terms besides "Father," such as "loving," "good," and "creator," but these are not in the same class as "God" and "Father" for him. Perhaps this is because these terms are descriptions, rather than names, and hence are in principle applicable to an indefinite set of subjects. The problem is that the same can be said for "God" and "Father." "God" is not a proper name, nor is it uniquely Christian. Theos, deus, Elohim, Allah: these are all loanwords. We use language of divinity when we associate a subject with some set of characteristics: being awe-inspiring, beautiful, powerful, etc. The Psalmist was presumably not conceiving of Yahweh as a polyonym when he wrote: "Know that the Lord is God. It is he who made us, and we are his" (Psalm 100:3 NRSV) or "The Lord is a great God, / and a great King above all gods. / In his hand are the depths of the earth; / the heights of the mountains are his also. / The sea is his, for he made it; / and the dry land, which his hands have formed" (Psalm 95:3-5). In both cases, Yahweh is being characterized as God, and this conceptual association is further explicated by praising Yahweh's kingship over the other gods and over the earthly realm, which he created. Since we are not in possession of any direct name for God, as we might be in the case of a fellow human being, we must rely on terms that evoke or describe ideas. Even Yahweh is explained through an etymology as meaning "I am who I am" (Exodus 3:14) or "I will be gracious to whom I will be gracious" (Exodus 33:19). In such a phrase as "The Lord is God," this title is in turn linked with the more general Hebrew term for deity and both terms are further qualified by language of creativity, formation, and royalty. On this way of understanding divine names, what occurs in the New Testament is not that the one God is identified with the Father, but rather that the concept of fatherhood is added to, or rather, given greater prominence within, this cluster of notions of deity, and at the same time, words like son, spirit, kyrios, and logos are given new significance and focused on Jesus of Nazareth. ${ }^{15}$

${ }^{13}$ Basil, Against Eunomius 1.8 (DelCogliano and Radde-Gallwitz 2011, 101).

${ }^{14}$ For "Father," see Basil, Against Eunomius 2.9, 2.22 (DelCogliano and Radde-Gallwitz 2011, 142; 164).

${ }^{15}$ Moreover, unlike Tuggy, the Cappadocians take term "father" as a relational term - that is, one that requires a correlative stating of what or whom the father is parent. 
This is my own way of putting the matter, but I think it's not too far from how Basil and Gregory of Nyssa understood divine "names" (Greek onomata, which in ordinary usage can refer to names, nouns, and adjectives). In his work To Eustathius, On the Holy Trinity - sometimes misidentified as Basil's Letter 189-Gregory reasons (1) that all divine terms except for Father, Son, and Spirit indicate the same subject, the divine nature, presenting it under distinct concepts and (2) that none of the three persons is excluded from any of those names. Gregory gives the examples of 'good,' 'just, 'powerful,' and 'wise.' Each of these is applied in the singular, even though predicated of the three persons. From this, Gregory reasons that it is a single goodness in the three persons, a single justice, and so on. There cannot be a definition of deity, so it is terms of this sort-perfection terms-that function as the components of the logos tês ousias when we speak of God. In effect, the simple way to think of this whole theory is that Basil and his younger brother have removed the option of speaking of God as a "thing," as anything at all like an Aristotelian primary substance. ${ }^{16}$ They did not, in other words, affirm both that God was a thing and not a thing, as Tuggy alleges. It is important to note that in the quotations he provides, he has inserted the glosses that make it seem as if they are equating the divine nature with God (understood as primary substance), something Basil and Nyssen never do. Nor, in removing the primary-substance sense of "god," were they left with an inert set of properties. Note how Basil understands the subject of Genesis 1:1: "In the beginning God made.' The blessed nature, ungrudging goodness, beloved by all who partake of reason, greatly desired beauty, principle of beings, source of life, intellectual light, unapproachable wisdom: this one 'in the beginning made the heaven and the earth.'"17 Basil here articulates, in a rhetorically powerful sentence, the set of causal and relational roles God fulfills in making the universe we inhabit. These causal and relational roles must be stated in general terms, given that they name relations of classes (e.g. rational beings, beings as such, living beings) to God. God is identified with these various perfections and, precisely because of this identification, is called the creator of all. Basil is not engaged in Trinitarian theology here, but the point about creation has Trinitarian implications, since for Basil, the various titles in the list are not divided among the three hypostases, as they had been in Origen's On First Principles, where the Son as Logos is participated in by rational beings only and the Father by all beings. The appeal to the single deity in the face of the tritheist accusation was therefore neither ad hoc-ery nor an appeal to an

\footnotetext{
16 Gregory in fact went so far as to claim, via an etymology, that "God" names a divine activity: see Radde-Gallwitz, Gregory of Nyssa's Doctrinal Works, chapter 3.

17 Basil, Homilies on the Hexaemeron 1.2.
} 
abstraction. As there is just one universe, there is only a single cause of that universe (one goodness, one deity, etc.), which is how Christians understand the term "God."

I have covered a very small range of texts, and I need to ward off one possible misunderstanding. The three names of the baptismal formula were not the only ones "allocated," so to speak, to the three persons. The Cappadocians noticed that "Son" is not the only name for the Son in scripture; he is also Only-begotten God, power and wisdom, the one Lord, the logos and so forth; additionally he is Good Shepherd, Christ, Son of Man, vine, etc. The Christological disputes were only in their infancy in the late fourth century and much of the debate that would ensue was over how to parse this complex of titles. The Holy Spirit is also Paraclete, life-giver, Spirit of Christ, Spirit of God, etc. And the Father is also the "one God" (1 Cor 8:6) and "the God over all" (Eph 4:6). Monarchian Trinitarians like Behr and Branson emphasize these descriptions of the Father, the first of which is routinely voiced by Christians in the Nicene-Constantinopolitan Creed. Behr has emphasized Gregory of Nyssa's claim in To Peter that the God over all is the Father. ${ }^{18}$ While it is true that Gregory frequently substitutes "God over all" for "Father," this interchangeability is less than decisive evidence for his espousal of Monarchian Trinitarianism. Gregory also in many cases cites Romans 9:5, where, on Gregory's reading, Paul applies the same phrase to Christ. ${ }^{19}$ Hence, the phrase "God over all" neither serves as a proper name for God nor differentiates Father from Son, though indeed it is one of the Father's scriptural descriptions. The broader point for present purposes is twofold: (1) the term "God" appears in complex ways in this catalogue; we do not start with a straightforward idea of God and then try to determine whether its extension is Father or Son or Spirit or some combination, and (2) no single title offers a complete depiction of any of the three persons; it follows that we do not start with such a clear conception of Father that we can equate it with God. One cannot therefore reduce theology to a simple identification of Father with God.

\section{Gregory of Nazianzus}

I have focused thus far on Basil and Gregory of Nyssa. Lest I be accused of dodging Tuggy's blow, I close by commenting briefly on four texts Tuggy cites from Nazianzen, who admittedly departs in certain ways from Basil and Nyssen.

First, when Tuggy quotes Nazianzen as saying that "the Godhead" (he theotēs) is "the thing we worship," the Greek here is to proskynoumenon. Translators typically

${ }^{18}$ John Behr $(2018,320-30)$.

${ }^{19}$ E.g. Antirrheticus adversus Apollinarem (GNO 3.1, 189.6, 208.21, 229.11, 230.13); De perfectione Christiana (GNO 8.1, 194.5, 9). 
use "thing" in cases like this for neuter passive participles, but the word carries no implication that the deity is a thing in the sense of an Aristotelian primary substance, and it certainly doesn't imply that the Trinity is a thing. Nazianzen is merely saying that he worships the deity. Similarly, when Nazianzen says "the divine nature," he does not mean "the divine entity," as Tuggy glosses it.

Second, the personal pronoun "him" ( $\alpha \hat{v} \tau \tilde{\omega})$ in Oration 31.33 points back to "Father," not to "Trinity."

Third, Tuggy quotes Oration 40.45 in such a way that implies that Gregory substitutes "holy Trinity" for "deity," thereby equating the two. That would indeed be a problem for my reading, since I take "Trinity" as a label for the three hypostases qua distinct (see the next paragraph). Fortunately, Gregory does not use "Trinity" as equivalent to "deity" there.

Fourth, Tuggy quotes an interesting section from Oration 39.11. Here is the passage, with sentences marked for ease of comment:

[A] And when I speak of God, be struck by one light and by three: [A.1] by three (

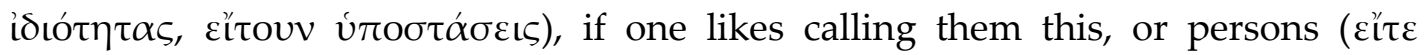

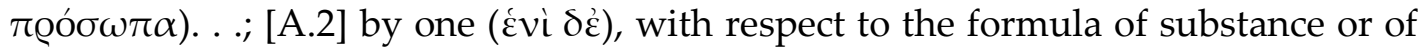

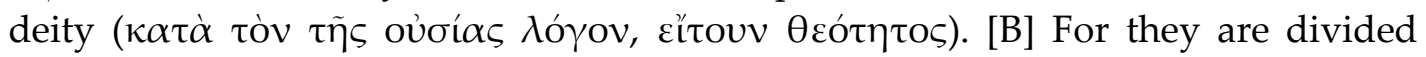
undividedly, so to speak, and connected dividedly. [C] For the deity is one ${ }^{20}$ in three, and the three are one, in whom the deity is, or to speak more accurately, who are the deity..$^{21}$

Tuggy detects here a confusion of universal essence with both individual reality and collective Trinity. However, the passage is more naturally read as restating the Basilian distinction between common and particular features, while also heading off one possible misunderstanding of that distinction. Thus, sentence A stipulates that the term "God" ought to conjure up a complex notion, which is at once three and one. The two elements are not contradictory since they reflect distinct, but equally fundamental facts, as stated the $\kappa \alpha \tau \alpha$ clauses of A.1 and 2; the word "God" conjures a subject that is in one way single and, in another, three, as Tuggy notes. Actually the complexity goes deeper, since both sides of this account contain both abstract conceptual elements (the single formula, the three distinctive features) and concrete

${ }^{20}$ The word is in the neuter here. It does not agree with "deity," which is feminine singular. It either picks up the neuter $\varphi \tilde{\omega} \varsigma$ (light) from the previous sentence (hence meaning "one light"), or it generalizes from that to any appropriate term identifying the common formula of being. Likewise in

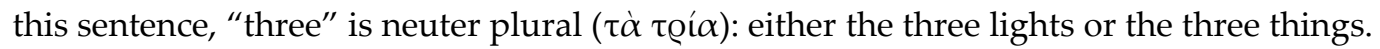

${ }^{21}$ Gregory of Nazianzus, Oration 39.11 (PG 36, 345C-D). 
realities (the single substance, the three hypostases or persons). So far, the account is Basilian.

The rhetorical paradox of sentence B presses beyond what we have seen in Basil or Nyssen. Nazianzen ensures that one does not separate the two fundamental facts into two utterly distinct notions rather than keeping them in a single, complex notion. So strong is the interpenetration of the two parts that in sentence C, Gregory implies that whatever it is about God that is one is also three (because the single deity is in the three) and whatever is three is also one (because the one deity is in the three and actually each of them is the single deity). The last point is the trickiest one; it would indeed entail Sabellianism if we took it as denying one of the fundamental facts, but Gregory immediately pivots to ward off that interpretation. So it seems that here again we have the complex notion identified above from Basil, even expressed with much of Basil's terminology, though elevated with rhetorical tension and with the accent placed on the integral unity of the complex notion of God.

In sum, even allowing for Nazianzen's rhetorical provocations and his differences from Basil and Nyssen, I don't see the error that Tuggy finds in the texts cited.

\section{Conclusion}

What I've said here is largely historical. I must admit that, like Tuggy, I find modern phrases like "the triune God" or "the tripersonal God" problematic shortcuts. Perhaps such tags are useful provisionally, but they threaten to reduce the inherently complex concept described by the Cappadocians to something incoherent, in precisely the way Tuggy worries that Trinitarian theology is not simply unbiblical but incoherent. I say these labels threaten to do so, because I'm not convinced as he is that all hope is lost for post-Cappadocian and post-Augustinian traditions. Still, Trinitarian theology cannot be reduced to a bumper sticker; it requires metaphysical subtlety and careful attention to how language works. The alternative is to trade in simplifications of both the pro-Trinitarian and antiTrinitarian varieties. It is not my intention to suggest that Trinitarian theology can draw only on the Cappadocians. Their texts have received careful attention since late antiquity, and there is ongoing scholarly discussion and debate over them. Their theology is not obviously wrong in the way Tuggy suggests it is, but I wouldn't dare suggest that it is without problems. ${ }^{22}$

\footnotetext{
${ }^{22}$ I would like to thank an anonymous reader for TheoLogica for helpful comments on an earlier draft of this article.
} 


\section{Bibliography}

Ayres, Lewis. 2004. Nicaea and its Legacy: An Approach to Fourth-Century Trinitarian Theology. Oxford: Oxford University Press. https://doi.org/10.1093/0198755066.001.0001.

Ayres, Lewis. 2010. Augustine and the Trinity. Cambridge: Cambridge University Press. https://doi.org/10.1017/CBO9780511780301.

Behr, John. "One God Father Almighty." Modern Theology 34 (2018): 320-30. https://doi.org/10.1111/moth.12419.

DelCogliano, Mark. 2010. Basil of Caesarea's Anti-Eunomian Theory of Names: Christian Theology and Late-Antique Philosophy in the Fourth Century Trinitarian Controversy. Leiden: Brill. https://doi.org/10.1163/ej.9789004183322.i-302.

DelCogliano, Mark. 2017a. "Eusebius of Caesarea, On Ecclesiastical Theology 2.12.7". In The Cambridge Edition of Early Christian Writings, Volume One: God, edited by Andrew Radde-Gallwitz, 114-15. Cambridge: Cambridge University Press.

DelCogliano, Mark. 2017b. "Ambrose of Milan, On the Faith 1". In The Cambridge Edition of Early Christian Writings, Volume One: God, 229-232. Cambridge: Cambridge University Press.

Karamonolis, George. Forthcoming. "Early Christian Philosophers on Concepts." In The Notion of Concept in Greek Philosohy, edited by G. Betegh and V. Tsouna. Cambridge: Cambridge University Press.

Lienhard, Joseph. Contra Marcellum: Marcellus of Ancyra and Fourth-Century Theology. Washington, D.C.: The Catholic University of America CUA Press, 1999.

Porphyry. 1992. On Aristotle's Categories. Translated by Steven K. Strange. Ithaca, NY: Cornell.

Radde-Gallwitz, Andrew. 2018. Gregory of Nyssa's Doctrinal Works: A Literary Study. Oxford: Oxford University Press.

https://doi.org/10.1093/oso/9780199668977.001.0001.

St. Basil of Caesarea. 2011. Against Eunomius. Transled by Mark DelCogliano and Andrew Radde-Gallwitz, 134-35. Fathers of the Church 122. Washington, D.C.: The Catholic University of America Press.

Vallicella, William F. 2019. "Divine Simplicity." In The Stanford Encyclopedia of Philosophy (Spring 2019 Edition), edited by Edward R. Zalta. URL: https://plato.stanford.edu/archives/spr2019/entries/divine-simplicity/.

Published Online: August 25, 2020 